\title{
Teachers and Parental Position on the Interdiction of Corporal Punishment in the Teaching and Learning of Mathematics
}

\author{
Isaac Owusu-Darko, Mavis Ansah, Doe Florence, and Belinda Owusu-Mintah
}

\section{ABSTRACT}

There has been an alarming interest and complain about the use of corporal punishment on the part of teachers and parents respectively in the teaching and learning process. Corporal punishment creates a peculiar perception of how stakeholders of schools perceived its impact on pupils' academic performance. The study, however, sought to investigate the perceived impact of corporal punishment on pupils learning outcomes in the teaching and learning of mathematics for selected schools in Techiman municipal. The methodology used for the study was a descriptive research design with a mixed paradigm. Both quantitative (in the form of pupils obtained scores in pre-test and post-test) and qualitative data (from teachers and parents' responses to questionnaires) were used. The findings revealed that there is a significant mean difference between pupils' performance about whether they were taught with corporal punishment or otherwise. Majority of the parents and teachers presumed that sometimes using corporal punishment helps and foster students to learn. Parents strongly disagreed to the complete ban of corporal punishment in the school. Teachers however consensus agreed that they occasionally use Corporal Punishment to help pupils learn It is recommended that corporal punishment usage in schools should not be banned entirely but rather, measures should be put in place to monitor how it is meted out in schools. Teachers should not abuse the use of corporal punishments in schools.

Published Online: September 21, 2021

ISSN: $2736-4534$

DOI :10.24018/ejedu.2021.2.5.2

Isaac Owusu-Darko*

Valley View University, Techiman Campus, Ghana.

(e-mail: iowusudarko@vvu.edu.gh)

Mavis Ansah

Valley View University, Techiman Campus, Ghana.

Doe Florence

SDA College of Education, Ghana.

Belinda Owusu-Mintah

SDA College of Education, Ghana.

*Corresponding Author

Keywords: Corporal punishment (CP), discipline, academic performance, teachers' perception, interdiction.

\section{INTRODUCTION}

Teaching and learning of mathematics have gone through enormous research into what could help the pupils or students learn hard. One cotemporally and orthodox approach deem primitive nowadays is the integration of corporal punishment in the teaching and learning of mathematics. How are there so many bans on the use of corporal punishment but most teachers in Ghana still hold to this practice. We investigate a case study of this situation in Techiman municipal selected basic schools to see the perception attached to the use of corporal punishment (especially canning) in the teaching and learning of mathematics.

According to Oxford dictionary (year), corporal punishment refers to the physical punishment of people especially by beating or hitting them. Similarly, [1]. Corporal punishment is the use of physical force with intention of causing a child pain, but not injury for the purpose of correction or controlling of the child's behavior.'

In the school setting, corporal punishment is normally used as corrective measure and also to control children's behavior. For instance, teachers use corporal punishment when a child misbehaves in class and also when a child fails to pay attention in class. Most parents and other stakeholders of education perceive corporal punishment as physical abuse and insist that corporal punishment in schools must be banned. Some parents go to the extent that corporal punishment is the cause of low academic performances in schools since it results in timidity among children making them inactive during lesson delivery. Alsaif [1] confirms the assertion that there is a difference between corporal punishment and physical abuse but others see both as abusive.

A study conducted by Wilson posited that corporal punishment is cheap and easy to administer. [2]. It does not need any sophisticated item and it does not waste pupils' time. It is also seen as an effective corrective measure that compels pupils to do the right thing.

Alsaif [1] commented on the reasons for resorting to corporal punishment. He revealed that corporal punishment in schools, helps children to avoid unhealthy behaviour and also builds in them the effort to improve upon their performances in the classroom. Some teachers are of the view that if corporal punishment is not allowed in schools, effective work cannot be achieved because if they resort to other corrective measures like counselling it would consume the pupils time but caning for instance does not waste time and it quickens the minds of pupils. Portela and Pells posited that advocates of corporal punishment believe that it is 
harmless form of enforcing discipline [3]. It makes pupils obedient and respectful.

On the other hand, corporal punishment has some negative effects. Corporal punishment might kill the interest of pupils in schooling due to how it is handled in the classroom. According to the American Psychological Association (APA) website corporal punishment causes undesirable responses in students such as low self- confidence or feeling that he or she is an undesirable person. These feelings may be frustrating for the child and make him miserable in class all the time. A child who does not find joy in school may not have any interest in attending school and this can result in school dropout.

Research has shown that the child learns well by imitating the behaviour of adults (teachers). Therefore, the use of physical punishment by adults having authority over children is likely to influence the training of the child in solving issues violently rather than persuasion, education, and intelligent forms of both positive and negative reinforcement. The examples exhibited by the teacher will lead the matured child to use corporal punishment because he did not learn how to solve problems logically from the role the muddling of his teachers. Some Educators believe that the prevention of corporal punishment will lead to the loss of prestige of teachers and the loss of their ability to manage their pupils.

According to South African Development of Education (2000a), corporal punishment appeared to be the accepted method of punishment for teachers. It is believed that some learners can only be disciplined through the use of corporal punishment [4].

A study conducted in 13 schools in a rural township in South Africa which largely populated by black learners revealed a mixed result pertaining to the use of corporal punishment [5]. It had both positive and negative effect. Even though it is banned, it is being practiced in some schools. What we want to find out it affect pupils learning outcomes positively all negatively.

The issue of corporal punishment in schools has received a great attention all over the world. Although corporal punishment in school setting has been banned and is illegal in some parts of the world, especially in Ghana, it remains a contested phenomenon in some communities in the country. Different perceptions are attributed to not only the use of corporal punishment in school, but the effect it brings. There is the need to investigate the nature of the effect of corporal punishment on the learning outcome of pupils as reflective in the teaching and learning process. Several authors, law practitioners and researchers have looked at this corporal punishment in different dimensions [6]-[8].

Corporal punishment has been accepted as the effective corrective measure by one side of a targeted group and the other side see it as abusive. In the learning environment, the child could be corrected with seriousness through some "threat" to enforce the correction (the learning behaviour) whilst the child, perhaps supported by parents might see the teacher enforcement to help the learner learn hard through corporal forces as "abusive". There is the need to find out the intention of the usage of corporal punishment by the teachers in their various classes practically through control measures to find out the impact of these measure in enhancing students learning outcome or otherwise.
Teachers may use corporal punishment based on their experience to influence pupils to learn harder, get serious on the learning encounter, prevent inattentiveness and passiveness, check on discipline, and not necessarily taking delight in infringing pain on the learner. Although teachers experienced corporal punishment negatively when they were children but their views on the use of corporal punishments varies and sees its impact in the future. No wonder they try to emulate it. If they did not like it, why then are they using it now? Perhaps, they now realize its usefulness in supporting teaching and learning. No wonder some teachers believe that the use of corporal punishment helps to improve learners' performance. It is necessarily so? There is the need then to look at it further whether the perception of the impact of corporal punishment holds on the learning outcome of students especially among Valley View University Basic School Complex (VVUBSC).

The awareness of the abolition of corporal punishment is high but the use of corporal punish is still prevailing in some schools especially in Ghanaian schools. Teachers steal the possible chance to use this. What is the rationale behind it use? This is quite debatable. There is the need to investigate the situation in Valley View University Basic School Complex (VVUBSC). In order to investigate further, there is the need to reconsider the practical implication of this through mixed design approach in which we explore further beyond qualitative into quantitative data analyses through control and experimental design analyses to find the mean difference between pupils who learn similar concepts with corporal punishments and those who do not.

A report from the Global Initiative to End All Corporal Punishment confirms that there is a ban on all forms of corporal punishment, and it is also affirmed by the directives from the Education Ministry. From the ongoing discussion it could inferred that corporal punishment has both positive and negative effect on the individual student and teachers and administrators ensure it usage as a disciplinary measures, [9]. The question we ought to find is does it have positive or negative effect on the learning outcomes of the child? Should it be banned completely in schools? These questions have prompted the researcher to find out whether corporal punishment has positive or negative influence on the learning outcomes of the basic school child. The researcher also wants to identify teachers and parents stand on the issue, whether it should be banned entirely or not especially in the context of religious institution such as VVUBSC.

\section{OBJECTIVE OF THE STUDY}

The specific objectives of the study were to:

1. Investigate whether corporal punishment has positive or negative impact on learning outcomes of students in Mathematics.

2. Examine teachers' reasons that stand for the use of corporal punishment in selected schools.

3. Find out parents' position on the ban on corporal punishment in schools). 


\section{LITERATURE}

Corporal punishment has been defined severally by scholars. The bases of their definitions do not differ from cultural attributions and the methodology deployed for such considerations. Some definitions address the way people (most especially parents) see the physical infringement of corporal punishments on the individual to which the punishment is affected. Ogbe defines corporal punishment as' an action either at home, in school to rebuke the child of wrong doing, as a means of molding the child towards better adulthood" [10]. Corporal punishment according to Ogbe is to help train a child to a better adulthood.

Tas also defines corporal punishment as "inflicting pain on the body of someone who presents undesired behaviour or does not present expected behaviour" [11], 12. To Tas, corporal punishment is seen as a corrective measure. Govender and Sookrajh (2014) also see corporal punishment as a way of reforming students or pupils.

According to Proctor [12], the use of discipline is necessary to provide obedience to school rules. However, the use of corporal punishment to provide discipline might cause more harm than good. In the same vain corporal punishment is one method of correcting, disciplining, helping pupils to learn of which Valley View University Basic School (VVUBS) is of no exception. As stipulated by Gershof and Font (2016) in Social Report on corporal punishment in US public schools that "corporal punishment initiates about improving school discipline." Even though it helps in instilling discipline in children some describe it as a mere inflicting pain on the individual as defined by some scholars.

A testimony by Donald Egreydanus, Md, Dr. HC(Athens) Professor of Paediatrics and Human Development, is of the view that corporal punishment infringe pain to pupils. $\mathrm{He}$ defines it as "intentional application of physical pain" as a method of ensuring behaviour change. The method of corporal punishment includes hitting, slapping, spanking, kicking, pinching. All these act air abusive.

Corporal punishment is seen by some researchers as the use of physical and mental punishment to bring about a desired change in the behaviours of children [13], [14]. VVUBSC, being a religious institution desire some kind of quality changes in the children entrusted in their care. In view of this the teachers require to train the children to meet the requirements in the school. Like the popular bible adage goes "spare the rod and spoil the child" they make sure the children obey the school rules and regulations so those who go contrary to the rules are brought to book.

\section{A. The Impact of Corporal Punishments on Pupils' academic Performances}

Miller [15] with his study "child abuse and neglect on severe physical punishment and exposure to animal cruelty by inmates convicted of felonies", he designed a questionnaire to assess the abusive childhood environments and exposure to animal cruelty. After administered to 314 inmates in a prisoners' classification centre His findings were consistent with the hypothesis that there is an association between punitive childhood histories and antisocial behaviour's. Some scholars support Millers idea [15]-[18]. They are of the view that if a child is subjected to severe punishment, he is likely to engage in antisocial behaviours.
The case of VVUBSC might seems quite different since it exists as a religious institution which instil disciplinary measures among pupils beyond corporal punishment. The issue of interest of which this study focuses is to find out the perceived effect of corporal punishment on the pupils in VVUBSC.

ARIF1 and RAFI2 [19], [20] with their study "effect of corporal punishment and psychological treatment on students" wanted to test the effect of corporal punishment and psychological treatment on students learning and their behaviour. It was found from the study that the students who were subjected to corporal punishment on creating a source of friction and showing lack of interest in their academic work began to show negative behaviour and their academic progress showed gradual regression, whereas those who were managed with psychological treatment developed their interest in learning, reflected friendly behaviour and improved their long-term scholastic performance. This implies that corporal punishment has negative impact on students' academic performance and behaviour Gredanus(nd) concluded his study by stating that' the use of corporal punishment in the school environment falsely and perfidiously reinforces physical aggression as an acceptable and effective means of eliminating unwanted behaviour in our society.

Ogando and pells [21] with their study into corporal punishment in schools; Longitudinal Evidence from Ethiopia, India and Vietnam, found that corporal punishment is highly prevalent in schools despite legal prohibition. Children interviewed revealed that they disliked school because of violence in schools including physical and verbal abuse from teachers and peers. They concluded that schools need to be safe, supportive, and enabling environment for all children to flourish. This implies that school environment must be free from violence to enable child growth and development.

Innocent [22] conducted a study to find out the impact of corporal punishment on students' academic performance in secondary schools with respect to religious implications. The study was conducted under three research objectives. These include to identify various impacts on corporal punishment of students' academic performance in secondary schools in Mbarara municipality, to identify the alternative to corporal punishment and to analyse how the administration of corporal punishment by the head teachers affect students' academic performances. The major findings of the study were that all schools have written rules and regulations, but they need modifications. Others lack consistence in their implementation which raises student's anger leading to violence, strikes and aggression. It could be inferred from this study that corporal punishment has negative impact on pupils' performance, so the study required an alternative to corporal punishment.

Similarly, a study on the effect of corporal punishment in Zanzibar primary schools [23]. The study identified, discussed and analysed data on various effects of corporal punishment on discipline and academic performance of primary school pupils. They used about 125 participants. A comparative case study design was used, and the focus was on four primary schools- two selected randomly and two selected purposefully. Data were collected using questionnaire as the main instrument of the data collection 
coupled with interviews, documentary review and observations. The result indicated that corporal punishment was poorly managed in schools not under alternative means to discipline project and that there is a community including teachers and parents' awareness on alternative means to discipline pupil.

These two literatures recommend alternative way of disciplining and handling them in the classroom. They see corporal punishment impacting negatively on pupils' performances because some are of the view that it would lead to aggression and aggressive cannot pay attention to whatever the teacher may impact to them. A section of parents of children in VVUBS are of the same view. They (parents) think corporal punishment could make their children aggressive and controlling would be difficult. They normally comment that since the school is religiously bound there should be other alternative to control pupils' behaviour rather than resorting to caning. However, some scholars view corporal punishment in a different way, they see it having positive impact on pupils' academic performances.

Makhasane and Chikoko [4] conducted a study on Corporal punishment contestations, paradoxes and implications for school leadership. The findings revealed that one hand corporal punishment was accepted, tried, and tested disciplinary measure in some South Africa high schools and on the other hand it was seen as violence and a thing of the past. This implies that corporal punishment has both positive and negative influence on pupils' performances.

Ogbe [10] analysed the perception of parents and teachers of the use of corporal punishment in primary schools in EdoDelta state. The purpose of the study was to find out parent and teachers' opinion on the need for continuity or discontinuity of corporal punishment among primary school pupils. The method he employed was descriptive study with the use of questionnaire. His sample size was 390.It was found in the study that both parents and teachers agreed that corporal punishment is an ideal practice for moulding children in primary schools. It was recommended among others that corporal punishment be restored where it is dysfunctional and there is the need to legislative law to protect teachers on their role in moulding of children in schools. Majority of teachers in VVUBS are of the same view with Ogbe. They think the only means to mould and discipline children for a change of behaviour is through the use of corporal punishment and that parent should allow them to use corporal punishment in the school. They are of the view that if corporal punishment is eliminated outright from school it could lead to indiscipline in the school and most especially low academic performance among the children. To them corporal punishment has a positive impact on the children performance.

Alsaif [1] with his study; Corporal Punishment in Schools: Theoretical Discussion and Experience throws further light on this. The paper first considers the benefits and faults of corporal punishment by comparing two generations of students and teachers. A quote from his introduction, 'he continued to cane students because he thought that this was the process to improve student's skills." This statement supports the argument that both teachers and parents supported corporal punishment being used in the schools in Saudi Arabia. The result of the study implies that corporal punishment has both positive and negative effects on pupils' performances.

According to Govender and Sookrajh [6], the perception of teachers and their past experiences influence their classroom discipline. Their study was guided by research objectives that examined, firstly teachers' perceptions of their past experience of corporal punishment and secondly, their perception of their disciplinary actions since the ban of corporal punishment in schools. Their data was collected through a qualitative research methodology of semistructured interview from seven primary school teachers in KwaZulu-Natal. The findings of the study showed that although teachers experienced corporal punishment negatively when they were pupils, their responses to the abolishment were varied, multiple and complex. Comparing this study to the issue of corporal punishment and its impact on pupils' academic performance in Valley View University Basic School, teachers perceive that corporal punishment can impact positively in pupils' academic performance due to their past experience on how corporal punishment aid them to achieve their aim in life. There is the need to investigate this phenomenon in VVUBSC.

A study on Technical High School Teachers views concerning corporal punishment. His results reveal that there exist significant differences between technical school teacher's attitude towards physical punishment in terms of where they work, their working years and their gender [11]. Likewise, teachers in VVUBSC have been seen having deferent views as to whether corporal punishment impact positively or negatively pupils' performances.

The argument so far depicts that corporal punishment is perceived to impact both positively and negatively on academic performances of pupils.

\section{B. Reasons for Using Corporal Punishment in Schools}

Investigation into ban of corporal punishment, [24] wanted to find out why people still use corporal punishment despite its ban. His specific objective was to find out the forms of punishment meted on students in Muthumbi, also to investigate both students and teachers' preferences in regards to correction of infractions in Muthambi Division. The study adopted a descriptive design. Stratified random sampling was used sample schools where teachers and student respondents were drawn from. The findings of the study helped the researcher to recommend future measures to curb indiscipline in schools. Comparatively the teachers of VVUBS have various reasons why they want to use corporal punishment in These include maintenance of control in their classes, observance of school rules and regulation and to improve learning in the pupils as stipulated by some researchers. Some researchers [25], [26] suggested some reasons why teachers use corporal punishment. First is about habit, tradition, and familiarity. They explained further that corporal punishment has been a routine in schools since times past. Since it has been widely socially accepted act in the educational fields' teachers find it normal to use it. It is even supported and encouraged by parents. Also, teachers derive the interest from their past experience on corporal punishment. If we compare this assertion to the reasons why teachers of VVUBS use corporal punishment in the school some normally compare the act to what is happening in other schools in Ghana, most 
especially some former schools of the children where they see corporal punishment as means to help children to be disciplined in all aspect of life including learning.

Corporal punishment is considered legitimate in schools when one wants to tackle discipline problems. In religious schools according to her, corporal punishment is encouraged and supported by particular interpretations of a religious text 'spare the rod and spoil the child'. For this reason, since VVUBS is a religious based school corporal punishment ought to be used there. To end her argument, she explained that corporal punishment is necessary to teach children respect and discipline. A school child needs to learn how to respect rules and also needs to be disciplined in order to be fit in to the society he or she finds him or herself.

According to Basic Rights Handbook- Education Rights in South Africa- chapter 19, a debate on corporal punishment revealed that leaners who received corporal punishment work harder [27]. According to spoke for the motion, banning corporal punishment has resulted in reduced levels of discipline in schools. Some teachers of VVUBS are of the same view that due to the ban corporal punishment school children do not take their lessons seriously and that has led to the fallen standards of education in the recent times. When pupils fail to do their homework there is no measure to check that if corporal punishment is not allowed in the school because there is limited time for other forms of correction.

Others posit that the purpose of corporal punishment is not to cause pain [28] but a disciplinary measure to control or manage pupils to avoid injury or to avert damage to property. Discipline as it is, comprises a lot and needs to be maintained in schools so as to inculcate the rights measures in other to fit in the society. The reasons that were given by the various researchers suggest that it should not be banned entirely but then measures must be taken to appropriate its usage or application. Kalaivani [29] also stated some reasons why corporal punishment is being used. He stated that lack of accountability towards children in schools can lead to teacher's usage of corporal punishment in schools. Many parents also ask teachers to beat their children. Moreover, some teachers are parents themselves who normally beat their own children in the home. This issue is indifferent in the case of VVUBS where some parents themselves buy canes for the teachers to discipline their children within the school. Allasan stated in his study that corporal punishment is used in schools by teachers because it causes pupils to change their bad behaviours [30].

\section{Perception of Pupils on Teachers Use of Corporal Punishment}

From the Executive summary of Human Rights Watch [31] when children are asked to choose between corporal punishment and the other alternatives like suspension they normally choose corporal punishment because to them corporal punishment would not give any evidence on the wrong things that have been done as compared to other forms like suspension. Others also see corporal punishment as quick and easy way of receiving punishment without waste of time. In this way they perceive the use of corporal punishment easy and quick way of being punished in the school as compared to the alternative forms of punishment.

Kalaivani stated that children obsessed with fear normally don't complain about punishment being meted to them [29]. They just accept it without any question, but they sometimes show signs of deep hurt in their behaviour. He went on to say that when corporal punishment is meted out to children, they become rebellious towards the teachers, resistant and some even take revenge. According to him when the students were interviewed some said that when the teachers punish them their friends make fun of them, and this make them feel mentally bad. It sometimes makes them hate teachers who melted out the punishment to them. The situation in VVUBS is not different, when students are punished the learners perceive the teachers as bad people. Some of the pupils do report such teachers to their parents and some go a long way to withdraw their kids from the school. To some of the pupils, corporal punishment should be a thing of the past, it is not needed in this modern 'world.

Most students perceive teachers who punish them in school as wicked and inconsiderate. This is confirmed by study conducted by Ramachandran and Subramanian [14]. They found that children who receive corporal punishment accept as a normal course of action especially during mathematics lessons. They see it as part of their training. To some of the pupils in VVUBSC, corporal punishment could be least expected since they see the institution as a Christian institution which should not play "wicked" on the part of a neighbour.

Kimani, Kara and Ogetange [32] with their study "teachers and pupils views on persistent use of corporal punishment in managing discipline in primary schools" revealed that corporal punishment was a regular school experience for the pupils. It was seen that corporal punishment was administered by people in authority including prefects. This study affirms assertion that school children see corporal punishment as a routine in the school. Pupils in VVUBS have it in mind that if they go contrary to any of the school rules, they would be punished so they see corporal punishment as a practice in the school.

Long [33] with his study on student and consequences associated with the use of $\mathrm{CP}$, disciplinary practices and alternatives throw lights on its effect on upper primary school pupils. The main consequences of disciplinary practices stated by students are low self- esteem, feelings of shame, anger, sadness, fear, pain, and hatred towards teachers. Per the little observation made with the pupils of VVUBS, teachers who normally beat those results in their hate and fear of such teachers. They complain a lot to their parents about these teachers showing their displeasure about the actions of the teachers.

\section{Parental Stand on the Use of Corporal Punishment}

Researchers [10], [34] investigated the perception of both teachers and parents on the use of corporal punishment in primary schools in Nigeria. The purpose of the study was to find out parents and teachers stand on whether to continue or to discontinue the use of corporal punishment in schools. It was found from the study that both parent and teachers support the act of corporal punishment in schools. He stated in his introduction that some parents in Nigeria gave a reason that corporal punishment help mould children to fit in to the society. In Ghana, every school has rules that govern the school. Teachers are mandated to lead child to observe such 
rules. In VVUBS most parent supports the use of corporal punishment in school and go to the extent of buying canes for the teachers to use in the school. Others are of the view that the school is a religious institution which should frown on the act of infringing pain on pupils.

Alsaif [1] post it that parents encourage teachers to use corporal punishment but not to be used violently. Parents of pupils in VVUBS are of the same views that corporal punishment could be implemented at the school, but it should be done with care. Khanal and Park [9] reported from their study that most teachers and parents thought that the best way to discipline children is punishment because it creates fear in the children and this avoid misconducts and promotes obedience. It also helps to improve academic performances.

Kindiki [8] conducted a research on 'investigating policy implication for the abolition of corporal punishment in secondary schools in Kenya'. He stated in his introduction that despite the ban on corporal punishment, some teachers, parents, education officials and students still have deep seated beliefs in the importance of corporal punishment due to the mismatch of children discipline at home and school. Some parents use corporal punishment in the home, so they expect teachers to do same at school.

\section{Methodology}

The research study is a descriptive study and the main design used was descriptive sample survey, which is mainly concerned with the description of some existing phenomenon about investigating the perceived effect of corporal punishment on students' academic performance. The researcher chose this for the study because he considered it to be the most appropriate one for the investigation. This is to help make a generalization based on the fraction of the population sampled in the case study in VVUBSC.

This design was considered appropriate because [35] indicates that it is oriented towards the administration of the status of a given phenomenon (herein considered as corporal punishment) rather than towards the isolation of causative factors. In this context, the study looked into the perceived impact of Corporal Punishment on the academic performance of students which is an existing phenomenon in VVUBSC.

[36] explains population as simply all the members of the group that you are interested in. The study population included parents, teachers, and pupils. The results of the data included views of parents, teachers and grades or scores from pupils work when taught with corporal punishment and when not taught with corporal punishment. The experimental group assessments of four classes of the upper class of the Valley View Basic school, specifically, classes four to JHS two. Two hundred and twenty (220) parents who attended this term (3rd term 2017/2018 academic year) PTA meeting was given the questionnaires to answer. 39 pupil's grades were used, and 25 teacher's views were sought. The total pupils' population purposively sampled was a census sampling size of 39 .

The main sampling technique adopted for the study was convenience sampling technique. Convenience sampling is selecting the research participants on the basis of being accessible and reasonably representative of the population of interest [37].

The sampling technique was used to sample 220 parents out of 700 parents in the Valley View University Basic School Complex (VVUBSC) in Techiman who attended the third term Parent and Teachers Association (PTA) meeting in the 2018/2019 academic year to answer the self-constructed questions. All the teachers at the Basic school parents (220) were selected.

Data collected for this study used a mixed system design approach where qualitative and quantitative data collections were considered, respectively. Quantitative data for the purpose of this study was collected from the academic records of students from the school teachers through a formal request for data by the headmistress after addressing these issues with school management committee of VVUBSC.

Secondary data source: the pre-test and post-test scores of students put into controlled and experimental group were recorded respectively for quantitative data analyses and inferences made on the bases of the research questions governing the survey. In all, there was $99 \%$ data collection of the questionnaire.

\section{DiscusSIONS}

The section of the study discusses empirical preliminary perception of parents towards the use of corporal punishment whether its needs to be discouraged at all or otherwise. Parents were asked whether they have heard any report on teachers use of corporal punishment (CP) in Valley View University Basic School Complex (VVUBSC). Responses are evident in Table I and II.

Table I gives respondent (parents) view on whether corporal punishment should be discouraged entirely or have heard any report on the use of corporal punishment in VVUBC. Out of the sample of 220 parents, 156 constituting $70.9 \%$ accepted the use of corporal punishment in teaching pupils, 64(29.1\%) refuted the use of it.

On whether parents have heard about any report on the use of corporal punishment in VVUBSC, 138respondent which constitute $62.7 \%$ of the total sampled parents have not received any report on the use of corporal punishment in VVUBSC 82(37.3) of the entire 220 respondents had received reports on the use of corporal punishment in VVUBSC.

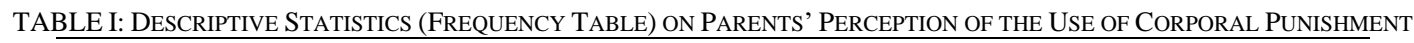

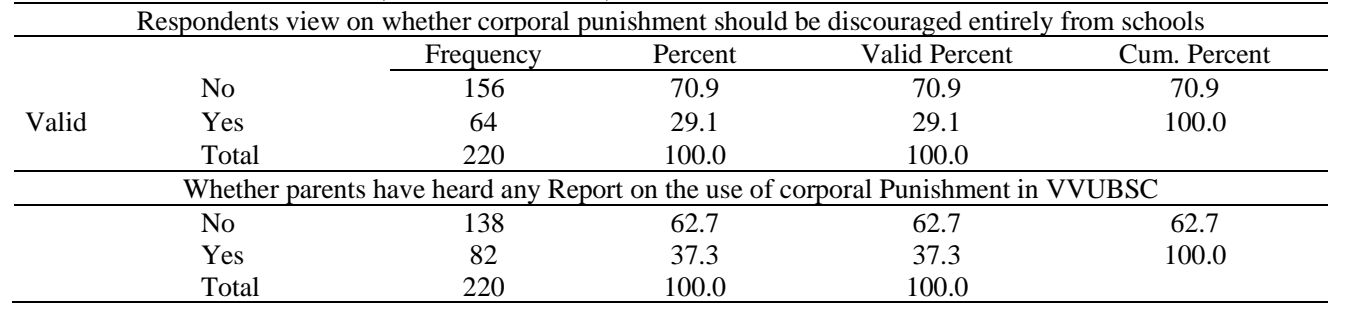


Views from Table I on parent's perception of the use of corporal punishment in VVUBSC and whether parents have any reports on the use of corporal punishment in VVUBSC could be summarized as even though, majority of parents have not got any report on the use of corporal punishment, most of them encouraged it use in the school if it had to be used.

TABLE II: PARENTAL STAND ON WHETHER TO DISCOURAGE OR ENCOURAGE CORPORAL PUNISHMENT

\begin{tabular}{cccc}
\hline \multicolumn{4}{c}{ Respondents view on discouraging or encouraging corporal } \\
punishment
\end{tabular}

A. Significance Test on the Difference between the Mean Performance of Control and Experimental Groups on the Use of $C P$

In order to find out whether $\mathrm{CP}$ has a significant effect on pupils' academic performance, an experimental study was affected on them. Pupils were put into control and experimental group with series of teaching by using an intervention of corporal punishment. A pre-test and post test scores were recorded. The data were analysed using the t-test statistics to find out whether there is a significant mean difference between the performances of these group. A correlational analysis was done find out the nature of the relationships. Fig. 1 shows the mean scatterplot of students' performance.

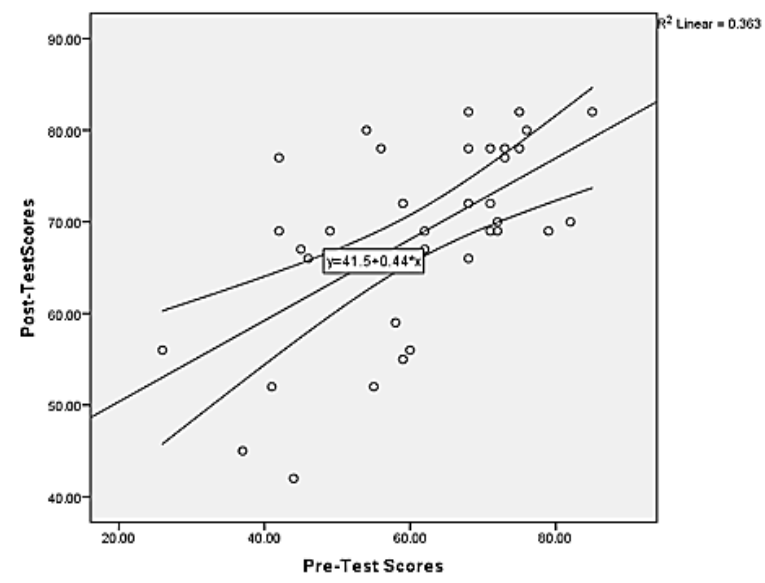

Fig. 1. Scatterplot with superimposed mean trend showing relationship between pupils' performance in pre-test and post-test.
The pre-test and post-test scores relationship with supperimposed best-fit line is shown from Fig. 1. The scatter-plot revealed a positive string relationship between the two assessments. The impact of $\mathrm{CP}$ on students marginally increases the performance proportionately by an average of 0.44. pupils had a constant score of $41.5 \%$ with a mean impact of 0.44 . this is evident in the regression equation:

$$
y=41.5+0.44 x
$$

where $y$ is the predicted post-test performance of pupils and $\mathrm{x}$ is the pre-test scores already obtained. Table III shows a paired samples descriptive statistics where the performances are compared.

From Table III, a paired sample descriptive statistics is given. Pre-test scores recorded a mean of 60.5385 with a standard deviation of 13.7 whilst the post test scores recorded a mean of $68.3333 \%$ with a standard deviation of 10.11 . There is a mean difference of about $7.8 \%$. the post test score however has a higher reliability coefficient evident in the standard error of the mean 1.6 as against pre-test scores of 2.2. There is a significant positive strong correlational measure of 0.602 . the correlation gives a direct relationship. This is similar to what the scatter plot directs in Fig. 1. There is a marginal increase in post-test scores of pupils relative to a unit increment of pre-test scores after the pupils are introduced to lessons and influencing their learning with corporal punishment. A significance mean test difference is seen from Table IV below.

There is the need to analyse the significant effect of $\mathrm{CP}$ on pupils' performance using the t-test statistics. A paired sampled t-test value of -4.376 was tested to be significant at $\alpha=0.01,0.05$ and 0.1 respectively. Hence there exist mean difference between student's pre-test and post-test scores respectively. Recorded scores of students after been influenced with corporal punishment strategies seems to have impacted positively.

\section{B. Whether Corporal Punishment Has Negative or Positive impact on pupils academic performance}

This section of data analyses further investigates into the impact of corporal punishment, whether the perception of it is directed positively or negatively. Figures and tables discussed here are descriptive.

\begin{tabular}{cccccccc}
\hline \multicolumn{7}{c}{ TABLE III: PAIRED SAMPLES DESCRIPTIVE STATISTICS } \\
\hline \multirow{2}{*}{ Pair 1 } & Mean & N & Std. Deviation & Std. Error Mean & Correlation & Sig. \\
\hline & Pre-Test Scores & 60.5385 & 39 & 13.74169 & 2.20043 & 0.602 & 0.000 \\
& $\begin{array}{c}\text { Post-Test } \\
\text { Scores }\end{array}$ & 68.3333 & 39 & 10.11339 & 1.61944 & & \\
\hline
\end{tabular}

TABLE IV: PAIRED SAMPLES T-TEST

\begin{tabular}{|c|c|c|c|c|c|c|c|c|c|}
\hline & & \multicolumn{8}{|c|}{ Paired Differences } \\
\hline & & \multirow[t]{2}{*}{ Mean } & \multirow{2}{*}{$\begin{array}{c}\text { Std. } \\
\text { Deviation }\end{array}$} & \multirow[t]{2}{*}{ Std. Error Mean } & \multicolumn{2}{|c|}{$\begin{array}{c}95 \% \text { Confidence Interval } \\
\text { of the Difference }\end{array}$} & \multirow[t]{2}{*}{$\mathrm{t}$} & \multirow[t]{2}{*}{ df } & \multirow[t]{2}{*}{ sig } \\
\hline & & & & & Lower & Upper & & & \\
\hline Pair 1 & $\begin{array}{c}\text { Pre-Test Scores - Post- } \\
\text { Test Scores }\end{array}$ & -7.795 & 11.124 & 1.781 & -11.40090 & -4.18885 & -4.376 & 38 & 0.000 \\
\hline
\end{tabular}


TABLE V: FREQUENCY TABLE FOR SELECTED PARENTS' VIEWS whether the use of corporal punishment in teaching and learning will

\begin{tabular}{|c|c|c|c|c|c|}
\hline & & Frequency & Percent & $\begin{array}{c}\text { Valid } \\
\text { Percent }\end{array}$ & Cum. Percent \\
\hline \multirow{6}{*}{ Valid } & Not at all & 35 & 15.9 & 15.9 & 15.9 \\
\hline & No & 33 & 15.0 & 15.0 & 30.9 \\
\hline & Not sure & 15 & 6.8 & 6.8 & 37.7 \\
\hline & Sometimes & 86 & 39.1 & 39.1 & 76.8 \\
\hline & Yes & 51 & 23.2 & 23.2 & 100.0 \\
\hline & Total & 220 & 100.0 & 100.0 & \\
\hline
\end{tabular}

\begin{tabular}{ccccc}
\hline \multicolumn{5}{c}{ Corporal punishment been the worse method to improve pupils } \\
performance \\
\hline Not at all & 58 & 26.4 & 26.4 & 26.4 \\
No & 85 & 38.6 & 38.6 & 65.0 \\
Not sure & 12 & 5.5 & 5.5 & 70.5 \\
Sometimes & 29 & 13.2 & 13.2 & 83.6 \\
Yes & 36 & 16.4 & 16.4 & 100.0 \\
\hline
\end{tabular}

Parental support of government policy on the band on corporal

\begin{tabular}{ccccc}
\multicolumn{5}{c}{ punishment } \\
\hline Not at all & 60 & 27.3 & 27.3 & 27.3 \\
No & 98 & 44.5 & 44.5 & 71.8 \\
Not sure & 2 & .9 & .9 & 72.7 \\
Sometimes & 8 & 3.6 & 3.6 & 76.4 \\
Yes & 52 & 23.6 & 23.6 & 100.0 \\
\hline Total & 220 & 100.0 & 100.0 & \\
\hline
\end{tabular}

This Table V represents the respondents view on whether the use of corporal punishment in teaching and learning will improve pupils' academic performance, has punishment been the worse method to improve pupils' performances and whether parent support government policy on the ban on corporal punishment or whether corporal punishment will improve pupils' academic performance. Out of the total number of parents sampled $86(39.1 \%)$ believe that sometimes corporal punishment improves pupils' academic performance, 51(23.2) responded that corporal punishment improves pupils' performances, 35(15.9\%) responded that not all circumstances that corporal punishment could be used, $33(15.0 \%)$ of the respondent do not accept the fact that corporal punishment improves pupils' academic performances and $15(6.8 \%)$ of the respondents are not sure whether it improves or it does not.

On corporal punishment being the worse method to improve pupils' performance 85 (38.6) of the respondents disagree, $58(26.4 \%)$ of the respondents believed that it should not be said at all, 36(16.4\%) affirm the notion, $29(13.2 \%)$ believe that sometimes it turns to be the worse method and 12 respondents are not sure whether it is worse or not. On parental stand on the governmental policy on the ban of corporal punishment, 98(44.5) do not support the policy, 60(27.3\%) do not support the idea. Fig. 2 is a pie chart representing the response on whether corporal punishment helps children to learn. The response proved that most parents responded in the affirmative way that it does help pupils to learn. About $37.27 \%$ of the respondents showed their disapproval of the issue.

It is evident from Fig. 2 that, $62.73 \%$ of the total 220 parents agreed (yes response) that $\mathrm{CP}$ indeed helps wards to learn compared to those who disagreed (with no response), a percentage of $37.27 \%$.

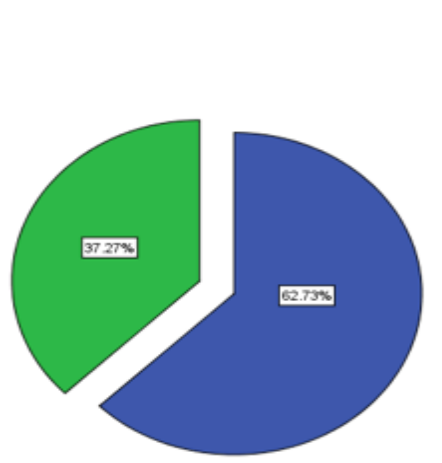

Fig. 2: Pie chart showing response on whether corporal punishment help pupils to learn.

\section{Parents Position on the Ban on $C P$}

This section discusses the research question surrounding Parent's position on the Ban on CP in schools. A cross tabulation for independent chi-square inferential statistics is looked at to test the hypothesis whether there is relationship between parental stand on the use of CP (either encouraging or discouraging its use) and the improvement of pupils' performance as seen from Table VI below.

TABLE VI: RELATIONSHIP BETWEEN PARENTAL STAND ON THE USE OF CORPORAL PUNISHMENT AND THEIR PERCEPTION ON WHETHER CP AFFECT

\begin{tabular}{|c|c|c|c|c|c|c|c|c|}
\hline \multicolumn{9}{|c|}{ STUDENTS' PERFORMANCE } \\
\hline & & \multicolumn{7}{|c|}{ Parent view on discouraging or encouraging corporal punishment } \\
\hline & & $\begin{array}{c}\text { Strongly } \\
\text { discourage }\end{array}$ & Discourage & Encourage & $\begin{array}{c}\text { Strongly } \\
\text { encourage }\end{array}$ & Chi-square & df & $\operatorname{sig}$ \\
\hline \multirow{6}{*}{$\begin{array}{l}\text { Whether the use of corporal } \\
\text { punishment in teaching and } \\
\text { learning will improve pupils' } \\
\text { academic performance }\end{array}$} & Not at all & 20 & 9 & 6 & 0 & 119.000 & 12 & \multirow{6}{*}{$.000^{*}$} \\
\hline & No & 10 & 15 & 2 & 6 & & & \\
\hline & Not sure & 2 & 1 & 12 & 0 & & & \\
\hline & Sometimes & 4 & 2 & 70 & 10 & & & \\
\hline & Yes & 8 & 4 & 30 & 9 & & & \\
\hline & Total & 44 & 31 & 120 & 25 & & & \\
\hline
\end{tabular}

Table VI gives a 4 by 5 contingency Pearson chi-square independence test between whether effect of $\mathrm{CP}$ on improving teaching and learning and parental support of it. Independent variable on parents' response is based on whether the effect is based on not at all, sometimes, rarely, and not rarely the claim under discussion. Parental response categorized on whether parent strongly disagree, disagree, encourage, or strongly encourage the use of corporal punishment in the Basic school under study.

The study sought to investigation the hypothesis that:
$\mathrm{H}_{0}$ : There does not exist a relationship between effect of $\mathrm{CP}$ on improving teaching and learning and parental support of it use.

\section{Against}

$\mathrm{H}_{1}$ : There exist a relationship between effect of $\mathrm{CP}$ on improving teaching and learning and parental support of it use.

At a significance level of $\alpha=0.05$, a decision precision level of $100(1-\alpha) \% \cong 95 \%$. A Pearson independent chi square is computed using an SPSS output estimator as 119.0. 
It is concluded here however that, there is no relationship between effect of $\mathrm{CP}$ on improving teaching and learning and parental support of it use and is it is tested to be significantly independent. Again, the fact that parents encourage or discourage the use of corporal punishment does not mean the perception that it affects teaching and learning holds true.

\section{Teachers Reasons for Using Corporal Punishment}

This section discusses teachers' reasons for using corporal punishment in the school under study. Responses are based on both parents and teachers' view on the given questionnaire.

TABLE VII: DESCRIPTIVE FREQUENCY TABLE ON REASONS FOR USING CORPORAL PUNISHMENT

\begin{tabular}{|c|c|c|c|c|c|c|c|c|c|}
\hline & & \multicolumn{2}{|c|}{ To ensure discipline } & \multicolumn{2}{|c|}{$\begin{array}{l}\text { To enhance teaching and } \\
\text { learning }\end{array}$} & \multicolumn{2}{|c|}{$\begin{array}{c}\text { To ensure students perform } \\
\text { well }\end{array}$} & \multicolumn{2}{|c|}{ As a means of intimidation } \\
\hline \multirow{7}{*}{ Valid } & & Freq & Percent $(\%)$ & Freq & Percent $(\%)$ & Freq & Percent $(\%)$ & Freq & Percent $(\%)$ \\
\hline & Strongly Disagree & 15 & 6.8 & 39 & 17.7 & 42 & 19.1 & 89 & 40.5 \\
\hline & Disagree & 44 & 20.0 & 35 & 15.9 & 29 & 13.2 & 71 & 32.3 \\
\hline & Agree & 106 & 48.2 & 89 & 40.5 & 87 & 39.5 & 29 & 13.2 \\
\hline & Strongly Disagree & 52 & 23.6 & 55 & 25.0 & 49 & 22.3 & 21 & 9.5 \\
\hline & Undecided & 3 & 1.4 & 2 & .9 & 13 & 5.9 & 10 & 4.5 \\
\hline & Total & 220 & 100.0 & 220 & 100.0 & 220 & 100.0 & 220 & 100.0 \\
\hline
\end{tabular}

Table VII gives a response on why teachers use corporal punishment. $106(48.2 \%)$ respondents believe that corporal punishment ensure discipline, $89(40.5 \%)$ responded that corporal punishment enhances teaching and learning, $87(39 \%)$ was of the view corporal punishment leads to improvement in pupils' academic performance.

A modal response of $56.36 \%$ of the respondents also agreed to the fact that the use of $\mathrm{CP}$ in the form of caning conforms to Biblical principles quoted by the Bible in Proverbs 22:6, 15 etc. below are few notable verses supporting this allusion/assertion:

$>$ Pr 20:11. Even a child is known by his doings, whether his work be pure, and whether it be right.

$>$ Pr 22:6: Train up a child in the way he should go: and when he is old, he will not depart from it. \{Train...: or Catechise $\}$ in...: Heb. in his way $\}$

$>$ Pr 22:15: Foolishness is bound in the heart of a child; but the rod of correction shall drive it far from him.

$>$ Pr 23:13 Withhold not correction from the child: for if thou beatest him with the rod, he shall not die.

$>$ Pr 23:24: The father of the righteous shall greatly rejoice and he that begetteth a wise child shall have joy of him.

$>$ Pr 29:15: The rod and reproof give wisdom: but a child left to himself bringeth his mother to shame.

About $75.1 \%$ disagreed to the abolishment of corporal punishment in schools. The consistent response of parents on quite a positive perception of its impact on the child discipline to put them on the right is highly highlighted.

\section{CONCLUSION}

This study sought to investigate the effectiveness of Geometer's Sketchpad application software on The Senior High School students' performance in learning quadratic graphs. It also considered how students perceive the use of the software in their learning of quadratic graphs. The study found that the use of Geometer's Sketchpad application software had positive effect on students' performance in quadratic graphs and also changed students' perception, attitudes as well as motivated them in their learning of quadratic graphs. This indicated that the GSP group would not avoid using the software to learn with. The positive attitudinal change detected in this study supported the works of [38] and [39].
The use of mathematical software such as Geometer's Sketchpad and Spreadsheet (Microsoft Office Excel), promote collaborative learning among students as was observed during the treatment sessions of this study. Consequently, it can be deduced from these findings that the use of relevant ICT tools could appeal to the diverse learning needs and styles of today's students.

\section{RECOMMENDATIONS}

We recommend that, African mathematics teachers integrate the current ICT tools in teaching and facilitating their instructional pedagogies such as Geometer sketchpad since this was tested to contribute to student understanding of graphing techniques. Students get involve in the lesson and tend to appreciate the adopted pedagogical approach.

\section{REFERENCES}

[1] O. A. Alsaif, "Corporal punishment in schools: theoretical discussion and personal experience," Contemp. Issues Educ. Res., 2015, [Online]. Available:

https://clutejournals.com/index.php/CIER/article/view/9058.

[2] B. Clark, "Why can't I discipline my child properly?'Banning corporal punishment and its consequences," S. Afr. Law J., 2020, [Online]. Available: https://journals.co.za/content/journal/10520/EJC$1 \mathrm{~d} 335 \mathrm{~cd} 3 \mathrm{f} 3$ ?crawler=true \&mimetype=application/pdf.

[3] M. J. O. Portela and K. Pells, Corporal punishment in schoolslongitudinal evidence from Ethiopia, India, Peru and Viet Nam. ideas.repec.org, 2015.

[4] S. D. Makhasane and V. Chikoko, "Corporal punishment contestations, paradoxes and implications for school leadership: A case study of two South African high schools," South African J. Educ., 2016, [Online]. Available: https://www.ajol.info/index.php/saje/article/view/149285.

[5] A. Gradwell, A survey of teachers' attitudes towards corporal punishment after the abolition of corporal punishment. etd.uwc.ac.za, 1999.

[6] D. S. Govender and R. Sookrajh, "Being hit was normal': teachers'(un) changing perceptions of discipline and corporal punishment," South African J. Educ., 2014, [Online]. Available: https://www.ajol.info/index.php/saje/article/view/105559.

[7] J. S. Agbenyega, "Corporal punishment in the schools of Ghana: Does inclusive education suffer?," Aust. Educ. Res., 2006, [Online]. Available:

https://link.springer.com/content/pdf/10.1007/BF03216844.pdf.

[8] J. N. Kindiki, "Investigating policy implications for the abolition of corporal punishment in secondary schools in Kenya," J. Educ. Adm. Policy, 2015, [Online]. Available:

https://academicjournals.org/journal/IJEAPS/articleabstract/29EE80E53196.

[9] J. Khanal, S. Park, and J. Education, "Corporal Punishment in Private Schools : The Case of Kathmandu ," vol. 7, no. 26, pp. 53-61, 2016.

[10] J. O. Ogbe, "Analysis of Parents/Teachers Perception of the Use of 
Corporal Punishment in Primary Schools in Delta and Edo State, Nigeria.," J. Educ. Pract., 2015, [Online]. Available: https://eric.ed.gov/?id=EJ1081191.

[11] J. A. Scutt, "Sparing parents pain or spoiling the child by the rod: Human rights arguments against corporal punishment," U. Tas. L. Rev. 2009, [Online]. Available: https://heinonline.org/hol-cgibin/get_pdf.cgi?handle=hein.journals/utasman28\&section=4.

[12] L. M. Proctor, “'Boys Must Be Beaten': Corporal Punishment, Gender, and Age in New Delhi Schools," Landscapes of Violence, 2015, [Online]. Available: https://scholarworks.umass.edu/lov/vol3/iss3/3/.

[13] G. Garza, Discipline, Corporal Punishment, and Suspension. ERIC, 1976.

[14] T. Ramadan, “,An International Call for Moratorium on Corporal Punishment, Stoning and the Death Penalty in the Islamic World “. 05.04. 2005." 2018.

[15] E. T. Gershoff, P. C. Miller, and G. W. Holden, "Parenting influences from the pulpit: Religious affiliation as a determinant of parental corporal punishment.," J. Fam. Psychol., 1999, [Online]. Available: https://psycnet.apa.org/doiLanding?doi=10.1037/0893-3200.13.3.307.

[16] H. B. Sheu, R. W. Lent, M. J. Miller, L. T. Penn, and ..., "Sources of self-efficacy and outcome expectations in science, technology, engineering, and mathematics domains: A meta-analysis," J. Vocat., 2018, [Online]. Available:

https://www.sciencedirect.com/science/article/pii/S000187911830113 1.

[17] A. L. Miller, "Corporal Punishment in Japan," Anthropol. Action, vol. 23, no. 1, pp. 39-45, 2016, doi: 10.3167/aia.2016.230106.

[18] G. W. Holden, P. C. Miller, and S. D. Harris, "The instrumental side of corporal punishment: Parents' reported practices and outcome expectancies," J. Marriage Fam., 1999, [Online]. Available: https://www.jstor.org/stable/354012.

[19] A. Mudinillah, "The Development of Interactive Multimedia Using Lectora Inspire Application in Arabic Language Learning," J. Iqra Kaji. Ilmu Pendidik., vol. 4, no. 2, pp. 285-300, Dec. 2019, doi: 10.25217/ji.v4i2.570.

[20] M. S. Sallau, P. A. Ekwumemgbo, S. Uba, and S. Zubairu, "(CS) to $2241.66 \pm 92.04 \mathrm{mg} / 100 \mathrm{~g}$ (FF) were recorded for Ca," Chinese Acad. Trop. Agric. Sci. China, vol. 21, no. 2, pp. 1-11, 2018, doi: 10.9734/JSRR.

[21] M. J. O. Portela and K. Pells, Corporal punishment in schools longitudinal evidence from Ethiopia, India, Peru and Viet Nam. repositorio.grade.org.pe, 2015.

[22] C. Chaney, A. Skipper, and A. Harvey, "Black Mega Churches: Attitudes towards corporal punishment and perceived guilt or innocence," Ment. Health. Relig. Cult., 2015, [Online]. Available: https://www.tandfonline.com/doi/abs/10.1080/13674676.2015.108253 9.

[23] A. H. Hassan and A. Bali, "Assessing the Effects of Corporal Punishment on Primary School Pupils' Academic Performance and Discipline in Unguja, Zanzibar," Int. J. Educ. Res., 2013, [Online]. Available: https://ijern.com/journal/December-2013/16.pdf.

[24] T. Morag, "The Ban on Parental Corporal Punishment in Israel-What Facilitated the Change?," Corpor. Punishm. Child., 2018, [Online]. Available:

https://brill.com/view/book/edcoll/9789004355972/BP000013.xml.

[25] T. Hodny, "corporal Punishment and Rules of Reason," J. Contemp. Leg. Issues, 2007, [Online]. Available: https://heinonline.org/hol-cgibin/get_pdf.cgi?handle=hein.journals/contli16\&section $=20$.

[26] F. J. Ryan, "From Rod to Reason: Historical Perspectives on Corporal Punishment in the Public School, 1642-1994.," Educ. Horizons, 1994, [Online]. Available: https://eric.ed.gov/?id=EJ487425.

[27] F. Veriava and T. Power, "Corporal punishment," Basic Educ. rights Handb., 2017, [Online]. Available:

http://section27.hambisana.com/wp-content/uploads/2017/02/Chapter19.pdf.

[28] A. Pallas, "Corporal punishment: Ancient practice in modern times," Clear. House A J. Educ., 1973, [Online]. Available: https://www.tandfonline.com/doi/pdf/10.1080/00098655.1973.114777 52.

[29] R. Kalaivani, "A Study on Corporal Punishment in Schools at Sivakasi," Int. J. Res., 2016, [Online]. Available: http://www.academia.edu/download/43445872/03_IJRG16_A02_48.p df.

[30] A. B. Alhassan, "School corporal punishment in Ghana and Nigeria as a method of discipline: A psychological examination of policy and practice," J. Educ. Pract., 2013, [Online]. Available: http://citeseerx.ist.psu.edu/viewdoc/download?doi=10.1.1.988.4278\& rep=rep1\&type $=$ pdf.

[31] F. Bates, "Corporal Punishment in Legal, Historical and Social Context," Man. LJ, 1982, [Online]. Available: https://heinonline.org/hol-cgi-

bin/get_pdf.cgi?handle=hein.journals/manitob12\&section=27.

[32] N. K. Gerald, M. K. Augustine, and T. B. Ogetange, Teachers and pupils views on persistent use of corporal punishment in managing discipline in primary schools in Starehe Division, Kenya. irlibrary.mmarau.ac.ke, 2012.

[33] S. S. Long, "Negative consequences of corporal punishment of children are unequivocal," J. Pediatr., 2018, [Online]. Available: https://www.jpeds.com/article/S0022-3476(18)30002-7/abstract.

[34] O. A. Okori and O. Jerry, "Improvisation and utilization of resources in the teaching and learning of science and mathematics in secondary schools in cross river state," vol. 16, no. Ahmed 2008, pp. 21-28, 2017.

[35] G. H. Olivier, Educators' perceptions of corporal punishment. repository.up.ac.za, 2011.

[36] I. Owusu-Darko, O. Yaw, and W. A. Hughes, "The effects of the knowledge of educational psychology on the academic performance of students in mathematics," World Wide J. Multidiscipl Ina. Res. Dev. WWJMRD, vol. 3, no. 1, pp. 42-50, 2017.

[37] I. Etikan, S. A. Musa, and R. S. Alkassim, "Comparison of Convenience Sampling and Purposive Sampling Comparison of Convenience Sampling and Purposive Sampling," ResearchGate, no. January 2016, 2017, doi: 10.11648/j.ajtas.20160501.11.

[38] R. M. Youssef, M. Attia, and M. I. Kamel, "Children experiencing violence II: Prevalence and determinants of corporal punishment in schools," Child Abuse Negl., 1998, [Online]. Available: https://www.sciencedirect.com/science/article/pii/S014521349800084 2.

[39] G. M. Akakpo, K. Nyarko, R. Boateng, "The effect of corporal punishment and math anxiety on math performance among junior high school students in Ghana," IFE Psychol. An, 2013, [Online]. Available: https://www.ingentaconnect.com/content/sabinet/ifepsyc/2013/00000 021/00000002/art00025. 